\title{
A Közkórházi Orvostársulat és Semmelweis Ignác Fülöp
}

Semmelweis Ignác Fülöpről, a szülészet és nőgyógyászat magyar egyetemi tanáráról sokat olvashatunk, könyveket, folyóiratokat, tudományos cikkeket; nézhetünk emléktáblákat és filmeket.

2018 - emlékév, évforduló, születésének immár 200. éve. Az emlékezés erkölcsi kötelem. Főhajtás.

$\mathrm{Az}$ orvostörténeti szakirodalom alig foglalkozik a Közkórházi Orvostársulattal, pedig az sokat tett „az anyák megmentője" emlékének ápolásáért. 1943-ban jelent meg a Társulat első ötven évének története (1. ábra).

A Közkórházi Orvostársulatot 1894-ben alapították, 1942-ig 17 elnöke volt. 1943-ban az emlékkötet szerzője, Raisz Dezső (1890-1969) volt az elnök. A Társulat évente Semmelweis-emlékelőadást tartott. Az előadók a magyar orvostudomány jelesei voltak. Köztük például egyik legnagyobb sebészünk, Pólya Jenő (1876-1945). Ố kétszer is előadott. Az előadások közül kiemelhető a fülészet professzorának, Rejtő Sándornak (1888-1945) 1939-ben tartott előadása „Semmelweis tana és az otogen sepsis" címmel.

\section{A KÖZKÓRHÁZI ORVOSTÁRSULAT}

\section{ELSŐ ÖTVEN ÉVE}

IRTA

RAISZ DEZSÔ DR

EGYETEMI RK. TANÁR, KÖZKOORHÁ̉ZI FốORVOS
Az említett Emlékkönyvben értékes adatok olvashatók az 1917 júniusában tartott igazgatótanácsi ülésről [1], amelyen Mansfeld Ottó főorvos javaslatára elhatározták, hogy ezentúl a közgyưlés ünnepi előadóját Semmelweisemlékéremmel jutalmazzák. Az 1919. december 20-i
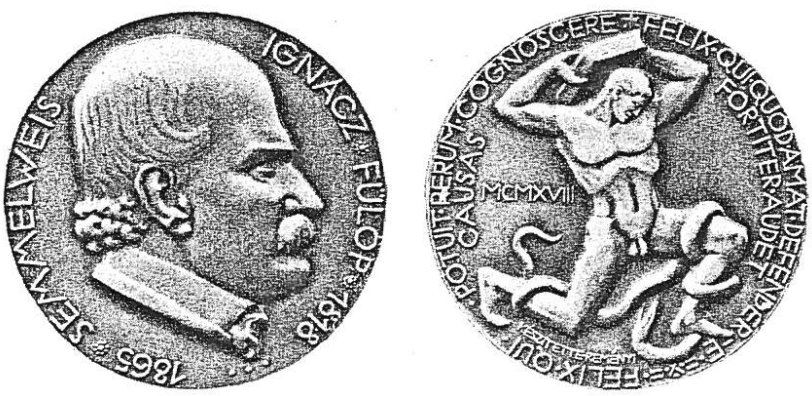

2. ábra | A Semmelweis-emlékérem

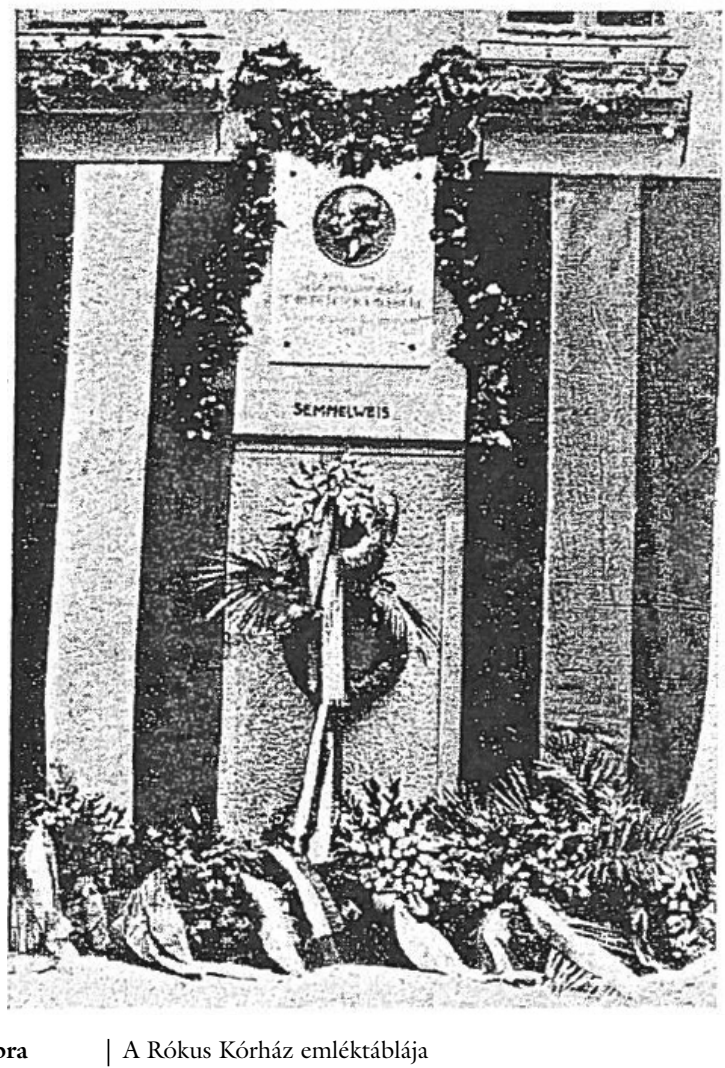




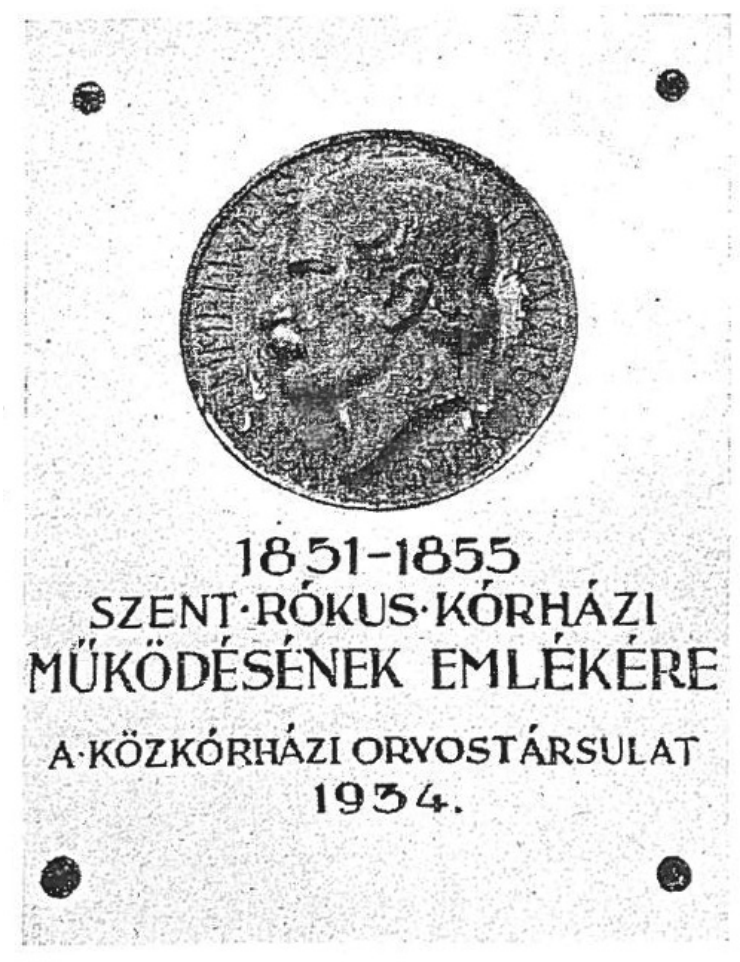

4. ábra $\mid$ Az emléktábla szövege

ülésen Manninger Vilmos már be is mutatja a Semmelweis-plakett mintáját. Az érem 1921-ben készült el (2. ábra).

A Társulat 1928-tól minden évben Évkönyvet adott ki, 1935-től pedig az Évkönyv közli a közgyúlésen tartott Semmelweis-előadás teljes szövegét is. 1937-tól az
Évkönyv címlapján a Semmelweis-emlékérem dombornyomatát viseli, első lapján pedig annak az emléktáblának képét, amelyet a Társulat Semmelweis emlékére a Rókus-kórház homlokzatán helyezett el (3. ábra).

Az emléktábla történetét így írja le a Társulat Emlékkönyve: (3., 4., 5. oldal szövege) „Az Igazgatótanács 1933. május 3-án ... a magyar haza dicsőségére” (4. ábra).

A Közkórházi Orvostársulat a II. világháború idején szúnt meg.

E sorok írója a magyar szülészet-nőgyógyászat egyik jeles képviselőjének, Dr. Lóránd Sándor egyetemi tanárnak a segítségével jött e világra. Később a tanítványa lettem, és meghívott munkatársának. Tőle hallottam az első Semmelweis-előadást az újpesti Árpád Kórház előadótermében. Elhozta a jeles előd egyik képét, és elmondta, hogy egy-egy ilyen kép van professzori szobájában, a szülőszzobában és otthoni rendelőjében. Boldog, amikor az egészséges édesanyák rámosolyognak újszülöttükre. Semmelweisról emlékezem - fejezte be -, hogy mindannyiunk példaképe legyen, és folytassák az Orvos hivatását: az édesanyákat szerető gondoskodást.

A szerző e helyen is köszöni Nyiri Krisztina értékes kreativitását.

\section{Irodalom}

[1] Raisz D. The first fifty years of the Public Hospital Medical Society. [A Közkórházi Orvostársulat első ötven éve.] Budapest, 1943. [Hungarian]

Vértes László dr.

"Nil sine magno vita labore dedit mortalibus." (Az élet küzdelmek nélkül nem ad semmit a halandóknak.) 